\title{
OCCUPATIONAL ORIENTATION IN CHEMISTRY-BASED LEARNING ENVIRONMENTS
}

\author{
Michael Albertus \\ Department of Chemistry Education, Freie Universität Berlin, Germany • \\ michael.albertus@fu-berlin.de \\ Claus Bolte \\ Department of Chemistry Education, Freie Universität Berlin, Germany • \\ claus.bolte@fu-berlin.de
}

\begin{abstract}
The research presented in this paper describes the German project "Career and Science Navigator (CSN)". This project ties in with previous studies, which indicate that it is necessary to include occupational orientation more strongly into science education. For this purpose, the CSN project developed some specific learning materials and learning environments. These learning environments were implemented into practice and then evaluated with the help of a questionnaire based on a career choice model, which has proven useful in earlier research. The CSN intervention was able to bridge the gap between chemistry education and the area of occupational orientation. It thus contributes to supporting young people in finding a meaningful perspective for their lives. Additionally the CSN conception offers a way to make science lessons more attractive to young people by directly referring to the students' everyday and future life.
\end{abstract}

\section{Introduction}

Following up the European debate on a future need of more young people taking up jobs in the area of the sciences (European Commission 2004, 181) the research of Bertels and Bolte (2009; 2010) focuses on occupational orientation in German chemistry classes as one major aspect in students' career choice. This research is especially valuable and important as there is already a lack of young people taking jobs in the sciences in Germany now (McKinsey 2011, 21). Additionally this lack will increase due to the demographic change in German society (Brenke \& Zimmermann 2005). The importance of research in the field of occupational orientation is also underlined by the "International Curricular Delphi Study on Science Education" (Bolte \& Schulte 2014). Results from this study about science education in Berlin show a mismatch between desirable and actual implementation of occupational orientation into science-related learning environments (Schulte \& Bolte 2014, 201).

Taking up these findings which clearly indicate a necessity of optimization e.g. in the form of an intervention linking chemistry education and occupational orientation more closely, the study presented in this paper evaluates an intervention called "Career and Science Navigator" (originally: "Berufe-NaWigator”).

\section{Research Question and Theoretical Framework}

The Career and Science Navigator (CSN) intervention examines the general question: To what extent do students feel supported in the process of occupational orientation within 
specifically developed chemistry- and at the same time occupation-related learning environments? Applied to the Career and Science Navigator intervention this question has to be modified as follows: How do the students participating in the Career and Science Navigator intervention feel supported in the process of occupational orientation?

To answer this question we adapted a research model by Bertels and Bolte (2010) which describes and operationalizes important factors influencing the students' career choice.

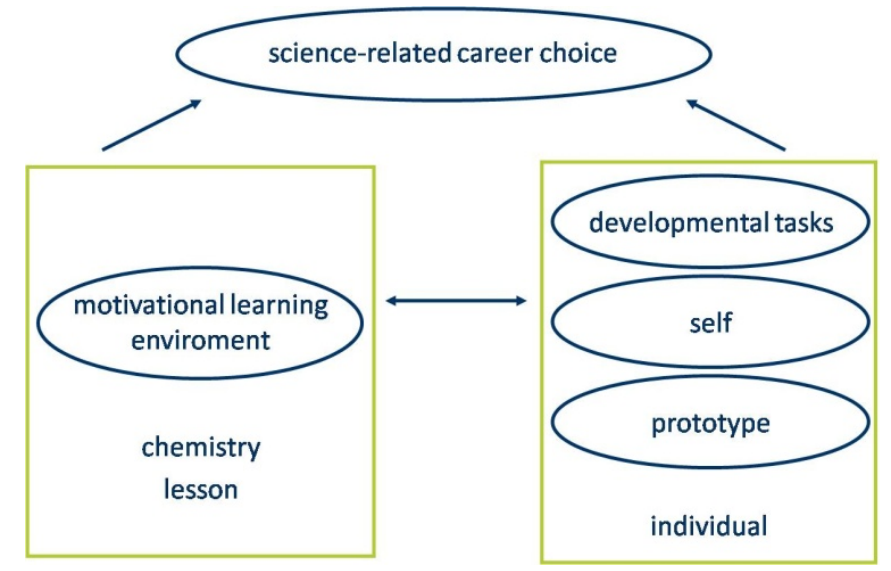

Figure 1 Research Model: Science related career choice (Bertels \& Bolte 2010)

This model consists of four major theories, each of them describing different impact factors on the students' science-related career choice (see Bertels and Bolte, 2010; Albertus et al., 2012). In this context Bertels and Bolte differentiate between two main impact factors influencing the science related career choice; on the one hand the students' chemistry lessons and on the other hand the individual. These factors are claimed to interrelate (Bertels \& Bolte, 2010). To characterize the chemistry lessons as such Bertels and Bolte used the model of the Motivational Learning Environment. This model is focusing the students' interest and motivation (Bolte et al., 2013).

In this paper we are mainly focusing on two of the theories included in the model mentioned above. These two theories will hence be described in the following.

Occupational orientation can be considered as a developmental task, which according to Havighurst's Developmental Task Theory (1981, VI) is a "midway between an individual need and a societal demand". In the context of science education there are specific developmental tasks which can and should be supported in science education practice (Schenk 2005). One of these specific tasks is to know which profession to take in the future and what conditions go along with different professions. This task is directly related to the process of occupational orientation and is referred to as "vocation".

The construct of developmental tasks was operationalized quantitatively and related to chemistry education by Bertels and Bolte (2009; 2010). Their research offers insights into the priority students attribute to the developmental task vocation against the background of 
how well they feel supported in coping with this task during their regular chemistry lessons on the one hand and the CSN intervention on the other hand.

The second theoretical grounding to evaluate the "Career and Science Navigator Learning Environments" is the so called self-concept. This theory is based on the cognitive representations an individual has about him- or herself (Kessels \& Hannover, 2006, 350). The self-concept is hierarchically structured and multifaceted (Shavelson et al. 1976, 412). There are two general categories in which the general self-concept is divided: the academic and the non-academic self-concept. Both of these categories are subdivided into several subareas (Shavelson et al. 1976, 413). In the context of occupational orientation the academic self-concept (e.g. the school-related or the chemistry-related self-concept) is especially relevant (Taskinen 2010, 59).

Other scales to determine individual changes regarding the students' career choice caused by the CSN intervention we adapted from the PISA Study 2006 (OECD 2009) and from Kessels and Hannover (2006) (see below).

\section{Method}

\subsection{Intervention Career and Science Navigator (CSN)}

In the course of the Career and Science Navigator (CSN) intervention, which should last a week, school classes take part in a specific learning arrangement in the Department of Chemistry Education of Freie Universität Berlin (FUB). During this five days stay at FUB the students learn about different occupations that require formal training such as laboratory chemist, chemical worker, pharmacist, specialist for sewage technology and specialist for food technology. At the same time the students practice typical operations of these occupations which are closely linked to chemical school experiments; like acid-base titration, burning sulfur, making an ointment, cleaning sewage and the production of soy milk.

\subsection{Evaluation of the CSN project}

The evaluation of the CSN project is based on the career choice research model by Bertels and Bolte (2010; see Figure 1). The questionnaires used to operationalize the cited model (Albertus et al. 2012) are also adapted to analyze the CSN project. Furthermore we supplemented the questionnaires of Bertels and Bolte by two scales from the PISA Study of 2006 (OECD 2009); namely the scales "Interest in Science" and "Information about Science Careers".

The participants of the Career and Science Navigator intervention are asked to complete the adapted questionnaire in the pretest version directly at the beginning of the intervention and finally in the posttest version at the end of the intervention (there are no major differences between the pretest version and the posttest version of the questionnaires). 
The results presented in this paper refer to the following aspects whose empirical scales are described in the next paragraph:

- developmental task: vocation (three times three items),

- the students' career choice intentions (six items),

- the students' interest in science (five items),

- the students' information about science careers (four items) and

- academic self-concept: school-related self-concept (five items) and chemistryrelated self-concept (four items).

The developmental task scale "vocation" provided by Bertels and Bolte (2009; 2010) in its short version (Albertus et al. 2012) consists of three items which have to be assessed by the students on a four-point scale:

\begin{tabular}{|c|c|c|c|c|}
\hline $\begin{array}{l}\text { The following aspects are especially important to me (my } \\
\text { personal life): }\end{array}$ & $\begin{array}{c}\text { fully } \\
\text { disagree }\end{array}$ & $\begin{array}{c}\text { rather } \\
\text { disagree }\end{array}$ & $\begin{array}{l}\text { rather } \\
\text { agree }\end{array}$ & $\begin{array}{l}\text { fully } \\
\text { agree }\end{array}$ \\
\hline $\begin{array}{l}\text { To be aware of what one should be good at in respect of different } \\
\text { occupations requiring formal training }\end{array}$ & 口 & 口 & 口 & 口 \\
\hline
\end{tabular}

As this example shows in the upper left cell of the table header there is the area where the point of reference (in this case: the priority of the students) is positioned. This part is varied to cover the different aspects related to the regular chemistry lessons ("Chemistry lessons support me in particular in the following aspects") and the CSN intervention ("The CSN project supported me in particular in the following aspects"). The developmental task items in each version of the questionnaire are identical, just the point of reference in the header is varied as described above.

To determine the students' career choice intentions we adapted the six items Bertels and Bolte used according to Kessels and Hannover (2006). These items have to be assessed on a four-point scale as well:

\begin{tabular}{lcccc}
\hline & $\begin{array}{c}\text { fully } \\
\text { disagree }\end{array}$ & $\begin{array}{c}\text { rather } \\
\text { disagree }\end{array}$ & $\begin{array}{c}\text { rather } \\
\text { agree }\end{array}$ & $\begin{array}{c}\text { fully } \\
\text { agree }\end{array}$ \\
\hline I would like to work in the chemical industry. & $\square$ & $\square$ & $\square$ & $\square$ \\
\hline
\end{tabular}

The items adapted from the PISA study 2006 to cover the students' interest in science also have a four-point scale. They can be exemplified as follows:

\begin{tabular}{lcccc}
\hline $\begin{array}{l}\text { To what extent do you agree with the following } \\
\text { statements? }\end{array}$ & $\begin{array}{c}\text { fully } \\
\text { agree }\end{array}$ & $\begin{array}{c}\text { rather } \\
\text { agree }\end{array}$ & $\begin{array}{c}\text { rather } \\
\text { disagree }\end{array}$ & $\begin{array}{c}\text { fully } \\
\text { disagree }\end{array}$ \\
\hline I am interested in learning something new in science. & $\square$ & $\square$ & $\square$ & $\square$ \\
\hline
\end{tabular}


The other scale from the PISA study 2006 covers the range of information the students have about science careers. They have to be ticked on a four-point scale as well:

\begin{tabular}{lcccc}
\hline $\begin{array}{l}\text { How well informed are you about the following } \\
\text { topics? }\end{array}$ & $\begin{array}{c}\text { Very well } \\
\text { informed }\end{array}$ & $\begin{array}{c}\text { Well } \\
\text { informed }\end{array}$ & $\begin{array}{c}\text { Not well } \\
\text { informed }\end{array}$ & $\begin{array}{c}\text { Not } \\
\text { informed } \\
\text { at all }\end{array}$ \\
\hline $\begin{array}{l}\text { Occupations related to sciences that are available on the job } \\
\text { market. }\end{array}$ & $\square$ & $\square$ & $\square$ & $\square$ \\
\hline
\end{tabular}

The scales regarding the academic self-concept are based on the scales from Schöne and her colleagues (2002). They have been adapted from Bertels and Bolte (2007) and refer to the school-related self concept on the one hand and to the chemistry-related self-concept on the other hand. The items for both sub-domains of the academic self-concept are similar and have to be assessed on a seven-point scale:

\begin{tabular}{|c|c|c|c|}
\hline At school I am ... & not talented & व & very talented. \\
\hline In chemistry lessons I am ... & not talented & प्व & very talented. \\
\hline
\end{tabular}

\section{Findings}

The total sample of this study consists of 95 students at the age of 13 or 14 from five different German middle school classes. Table 1 shows the results of the developmental task scale vocation. The participants of the CSN intervention assess their wish to be supported in this task on a 4-stage scale with an average of 3.2 (SD 0.5). At the same time the students describe the support in dealing with the task vocation during their regular chemistry lessons with 2.1 (SD o.8). In contrast to that the support in dealing with the developmental task vocation during the intervention Career and Science Navigator is indicated with 3.4 (SD 0.5) by the participants.

Table 1 Evaluation of the learning arrangement Career and Science Navigator - Developmental Task Scale: Vocation (1-not at all; 2.5- neutral assessment; 4-very much)

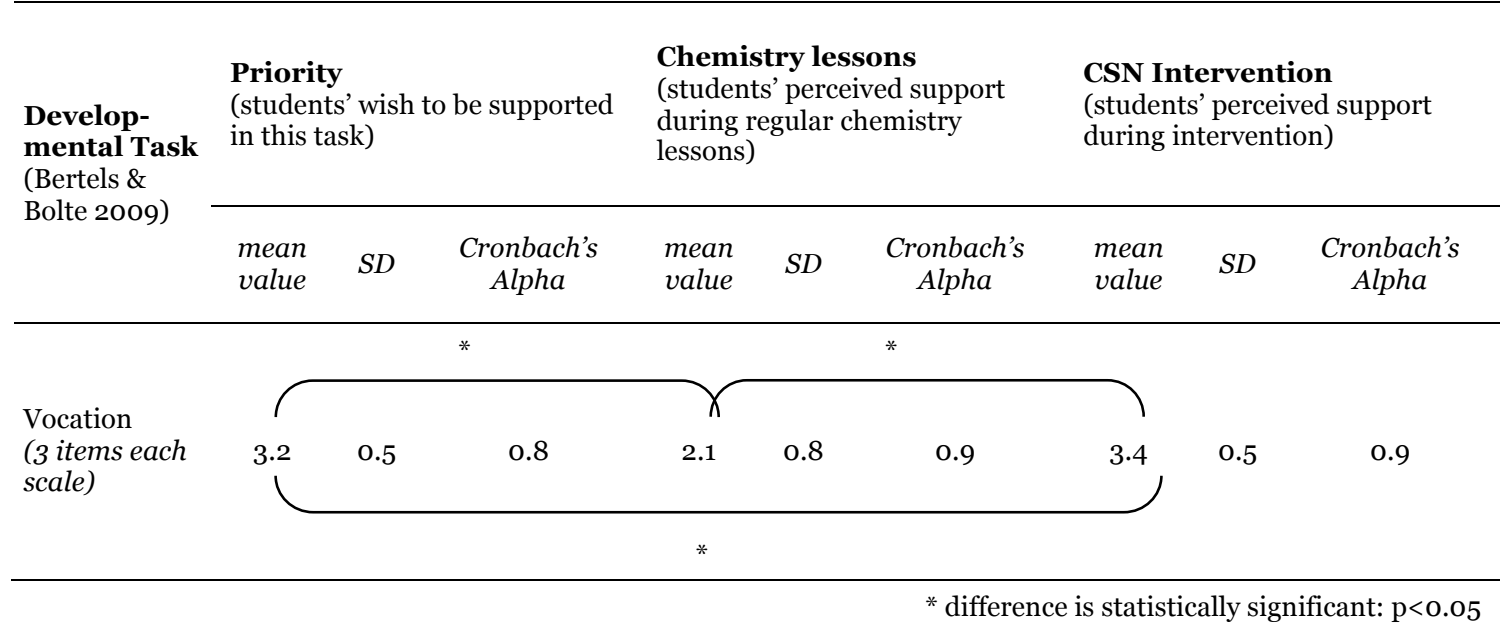


The results for the students' career choice intentions, their interest in science and the range of the students' information about science careers are summarized in Table 2. During the Career and Science Navigator intervention the students' career choice intentions raised from 2.1 (SD 2.7) to 2.4 (SD 0.7) on average. This effect is statistical significant and can be assessed as a middle large effect. At the same time the students' interest in science remained stable at a value of around 2.7 (SD 0.8). The perceived extent of the students' information about science careers increased from 2.2 (SD 0.5). to 2.8 (SD 0.8). This effect is statistical significant and can be considered as large.

Table 2 Evaluation of the learning arrangement Career and Science Navigator - Career choice intentions / PISA Scales (1-disagree; 2-rather not agree; 3-rather agree; 4-fully agree)

\begin{tabular}{|c|c|c|c|c|c|c|}
\hline \multirow{2}{*}{$\begin{array}{l}\text { Career choice Intentions } \\
\text { - Scale }{ }^{\text {a) }} \text { (Kessels \& } \\
\text { Hannover 2006) / } \\
\text { PISA Scales b) (OECD 2009) }\end{array}$} & \multicolumn{2}{|c|}{$\begin{array}{c}\text { Before } \\
\text { Intervention } \\
\text { (pretest-data) }\end{array}$} & \multicolumn{2}{|c|}{$\begin{array}{l}\text { After Intervention } \\
\text { (posttest-data) }\end{array}$} & \multirow{2}{*}{$\begin{array}{l}\text { Reliability of scales } \\
\text { Cronbach's Alpha }\end{array}$} & \multirow{2}{*}{$\begin{array}{l}\text { Effect size } \\
\text { Cohen's d }\end{array}$} \\
\hline & $\begin{array}{l}\text { mean } \\
\text { values }\end{array}$ & $S D$ & mean values & $S D$ & & \\
\hline $\begin{array}{l}\text { Wish to take a Science Career } \\
\text { a) } \\
\text { (6 items) }\end{array}$ & 2.1 & 0.7 & 2.4 & 0.7 & 0.9 & $0.7^{*}$ \\
\hline $\begin{array}{l}\text { Interest in Science b) } \\
\text { (5 items) }\end{array}$ & 2.7 & 0.8 & 2.8 & 0.8 & 0.9 & 0.3 \\
\hline $\begin{array}{l}\text { Information about Science } \\
\text { Careers b) } \\
\text { (4 items) }\end{array}$ & 2.2 & 0.5 & 2.8 & 0.6 & 0.8 & $1.5^{*}$ \\
\hline
\end{tabular}

* pretest-posttest difference is statistically significant: $\mathrm{p}<0.05$

Table 3 presents the results for the academic self-concept scales. In the pretest the students describe the school-related self-concept with 4.9 (SD o.8) and in the posttest the students specify this self-concept with 5.1 (SD o.8). This increase is statistical significant and has to be interpreted as a small effect.

Table 3. Evaluation of the learning arrangement Career and Science Navigator - school- and chemistry-related (academic) self-concept (1-negative; 4-neutral; 7-positive)

\begin{tabular}{|c|c|c|c|c|c|c|}
\hline \multirow{2}{*}{$\begin{array}{l}\text { Self-concept scales } \\
\text { according to Bertels and Bolte } \\
(2007) \quad \text { (originally: Schöne } \\
\text { et al. 2002) }\end{array}$} & \multicolumn{2}{|c|}{$\begin{array}{c}\text { Before } \\
\text { Intervention } \\
\text { (pretest-data) }\end{array}$} & \multicolumn{2}{|c|}{$\begin{array}{l}\text { After Intervention } \\
\text { (posttest-data) }\end{array}$} & \multirow{2}{*}{$\begin{array}{c}\text { Reliability of scales } \\
\text { Cronbach's Alpha }\end{array}$} & \multirow{2}{*}{$\begin{array}{l}\text { Effect size } \\
\text { Cohen's d }\end{array}$} \\
\hline & $\begin{array}{l}\text { mean } \\
\text { values }\end{array}$ & $S D$ & mean values & $S D$ & & \\
\hline $\begin{array}{l}\text { chemistry-related self-concept } \\
\text { (4 items) }\end{array}$ & 4.3 & 1.4 & 4.8 & 1.4 & 0.9 & $0.6^{*}$ \\
\hline
\end{tabular}

* pretest-posttest-difference is statistically significant: $\mathrm{p}<0.05$ 
The effect for the chemical self-concept is also statistical significant. It can be characterized as middle large effect. The students' assessment of the chemical self-concept develops from 4.3 (SD 1.4) in the pretest to 4.8 (SD 1.4) in the posttest.

\section{Discussion and Conclusion}

The results for the developmental task vocation show that the students' do not feel sufficiently supported in dealing with this task in their regular chemistry lessons. A clear difference between the students' priority and the actual support in their chemistry lessons indicates potential for optimization. This fact confirms the earlier findings by Bertels and Bolte (2009; 2010) and simultaneously attests the persisting necessity of interventions in this field as recommended in this contribution.

More encouraging are the findings regarding the students' support in dealing with the developmental task vocation during the intervention Career and Science Navigator.

With the help of the intervention we were able to even exceed the students' expectations by a value of $\Delta$ o.2. Hence the Career and Science Navigator learning environments can be seen as a positive example to be adapted for regular chemistry lessons.

Also the results for the other scales described above underline a positive effect of the Career and Science Navigator intervention on the students' process of occupational orientation.

The students' intentions to take a chemistry-related career for example increased about $\Delta$ o.3. Even larger is the effect of the CSN intervention on the students' extent of feeling informed about science careers $(\Delta 0.6)$.

Obviously the students are more likely to take a science career if they know many different science-related occupations. A lack of information about science careers could thus make students not choose a science career. This conclusion should be investigated in future studies.

Additionally in the context of the Career and Science Navigator intervention we were able to influence the students' academic self-concept; especially the school-related and the chemistry-related self-concept. The school-related $(\Delta+0.2)$ as well as the chemistry-related self-concept $(\Delta+0.5)$ developed in a positive manner. As the science-related self-concept is very important to the process of occupational orientation in the field of the sciences (Taskinen 2010, 50) the influence of the CSN intervention in this respect is also exemplary for school contexts. Due to the results obtained in our study the CSN intervention can be seen as a good example for a learning arrangement which links chemistry education to the process of occupational orientation.

All in all the Career and Science Navigator intervention contributes to optimizing the support of young people in finding a meaningful occupational perspective for their lives. As the CSN intervention has been carried out as an out-of-school learning arrangement first, it can and should be transferred into school. Hence, next steps would be to train teachers and at the same time to implement the CSN conception into general chemistry lessons in school. 
In the long run there is also the opportunity to adapt and evaluate the CSN conception for other science subjects (such as biology and physics). Apart from that the CSN conception can be extended to other occupations in the field of the sciences (e.g. optician, glassblower, laboratory biologist). A further step would be to analyze the long-term effects caused by the CSN intervention and to extend the intervention.

\section{References}

Albertus, M., Bolte, C., Bertels, N. (2012). Analyzing the Relevance of Science Education from Students' Perspectives regarding Developmental Tasks, Self and Prototype Attitudes and Motivation. In Bolte, C., Holbrook, J., \& Rauch, F. (eds.). Inquiry-based Science Education in Europe: Reflections from the PROFILES Project. University of Klagenfurt (Austria), 75-78.

Bertels, N., Bolte, C. (2007): Fragebogen zur Analyse naturwissenschaftsbezogener Berufswahlentscheidungen von Jugendlichen. (unpublished).

Bertels, N., \& Bolte, C. (2009): Developmental Task, Stereotypes and Motivational

Learning Enviroments in Science Lessons (in Germany). Proceedings of the Annual Meeting of the National Association for the Research on Science Education (NARST), Los Angeles, USA, April 2009.

Bertels, N., \& Bolte, C. (2010). Occupational Orientation - A Foreign Concept to Chemistry Lessons. Proceedings of the Annual Meeting of the National Association for the Research on Science Education (NARST), Philadelphia, USA, March 2010.

Bolte, C., \& Schulte, T. (2014). Stakeholders' Views on Science Education in Europe: Method and First Insights of the PROFILES International Curricular Delphi Study on Science Education. In C. P. Constantinou, N. Papadouris, \& A. Hadjigeorgiou (Eds.), E-Book Proceedings of the ESERA 2013 Conference: Science Education Research For Evidence-based Teaching and Coherence in Learning. Part 8 (co-ed. M. Ossevoort \& J. A. Nielsen) (pp. 131-142). Nicosia, Cyprus: European Science Education Research Association. Retrieved from http://www.esera.org/media/esera2013/Claus_Bolte_19Dec2013.pdf (12.06.2014).

Bolte, C., \& Schulte, T. (2012). Deliverable D3.2. PROFILES - Report to Stakeholders concerning 'WP3: Stakeholder Involvement' and Stakeholders Views regarding a Contemporary Inquiry Based Science Education. Unpublished Report to European Union.

Bolte, C., Streller, S. and Hofstein, A., (2013), How to motivate students and raise their interest in chemistry education, in Eilks, I. and Hofstein, A. (eds.) Teaching Chemistry - A Studybook, (pp. 67-95). Rotterdam: Sense Publishers.

Brenke, K., \& Zimmermann, K. F. (2005). Demographischer Wandel erfordert Bildungsreformen und lebenslanges Lernen. In: Wochenbericht des DIW Berlin. 19/2005. 329-335.

European Commission. (2004). Europe needs more scientists: Report by the high level group on increasing human resources for science and technology. Brussels: European Commission.

Havighurst, R. J. (1981): Developmental Tasks and Education (3rd ed.). New York and London: Longman.

Hannover, B., \&Kessels, U. (2004). Self-to-prototype matching as a strategy for making academic choices. Why high school students do not like math and science. Learning and instruction, 14(1), 51-67.

Kessels, U., \& Hannover, B. (2006). Zum Einfluss des Image von mathematischnaturwissenschaftlichen Schulfächern auf die schulische Interessenentwicklung. In Prenzel, M., Allolio-Näcke, L. (Hrsg.).Untersuchungen zur Bildungsqualität von Schule. Münster: Waxmann, 350-369.

McKinsey Deutschland (2011). Wettbewerbsfaktor Fachkräfte - Strategien für Deutschlands Unternehmen. Berlin: McKinsey \& Company, Inc.

OECD (2009). PISA 2006. Technical Report. Paris: OECD. 
Schenk, B. (2005): Entwicklungsaufgaben und Schule. In: Schenk, B. (Hrsg.): Bausteine einer Bildungsgangtheorie. Wiesbaden: Verlag für Sozialwissenschaften, 275-289.

Schöne, C., Dickhäuser, O., Spinath, B., Stiensmeier-Pelster, J. (2002): SESSKO. Skalen zur Erfassung des schulischen Selbstkonzepts. Göttingen: Hogrefe.

Schulte, T., Bolte, C. (2014). Stakeholders' views on empirically based concepts for science education to enhance scientific literacy - results from the third round of the international profiles curricular Delphi study on science education. In C. P. Constantinou, N. Papadouris, \& A. Hadjigeorgiou (Eds.). E-Book Proceedings of the ESERA 2013 Conference: Science Education Research For Evidence-based Teaching and Coherence in Learning. Part 8: Pre-service science teacher education (co-eds.: M. Ossevoort, J. A. Nielsen). Nicosia, Cyprus: European Science Education Research Association. pp. 197-

204. http://www.esera.org/media/eBook_2013/Strand\%208/ESERA_eBook_Part_8.pdf (Status: 2014-06-11).

Shavelson, R. J., Hubner, J. J., \& Stanton, G. C. (1976). Self-concept: Validation of construct interpretations. Review of educational research, Vol. 46, No. 3, 407-441.

Taskinen, P. H. (2010). Naturwissenschaften als zukünftiges Berufsfeld für Schülerinnen und Schüler mit hoher naturwissenschaftlicher und mathematischer Kompetenz: eine Untersuchung von Bedingungen für Berufserwartungen (Doctoral dissertation, Christian-Albrechts-Universität zu Kiel). 
ALBERTUS \& BOLTE 